\title{
Finance and Firm Export in China
}

\author{
Jun Du* and Sourafel Girma
}

\section{INTRODUCTION}

Although China has won many plaudits for its rapid transformation from an autarky to the world's largest recipient of foreign direct investment $(\mathrm{FDI})^{1}$ and a regional export power-house, some economists - most notably Huang (2003, 2004)- are less sanguine about the Chinese government's long-standing policy that encourages export-oriented FDI. Their main concern seems to be that foreign firms, especially those in labour-intensive industries, divert exports away from financially-constrained indigenous private enterprises.

The Chinese banking system has a reputation of lending bias against private firms (e.g. Allen et al. 2005). Until 1998, the four state-owned commercial banks which dominate the banking system in $\mathrm{China}^{2}$ were instructed not to lend to private enterprises. Huang (2003) contends that because of this financial repression, domestic private firms found it difficult to engage in contractual arrangements with foreign buyers ${ }^{3}$, creating a fertile condition for foreign firms to extend equity financing instead. According to this line of argument, a large proportion of export-oriented FDI in China is due to the bias of the financial system that favours stagnant state-owned enterprises over more dynamic private enterprises. As such, the huge flow of FDI into the country should not necessarily be an indicator of the strength of the economy.

* Contact details: Jun Du: Aston Business School, Aston University Birmingham, B4 7ET, United Kingdom. E-mail: j.du@aston.ac.uk. Sourafel Girma: Nottingham University Business School Jubilee Campus, Wollaton Road, Nottingham, NG8 1BB, United Kingdom. E-mail: sourafel. girma@nottingham.ac.uk. We gratefully acknowledge the constructive comments by Martin Hoskins. Girma benefited from an ESRC grant under its National and International Aspects of Financial Development program.

1. See 'Trends and Recent Developments in Foreign Direct Investment'. OECD Directorate for Financial, Fiscal and Enterprise Affairs. June 2004.

2. These four banks are the only financial institutions that have branches in almost all locations in China, and by 2001 they accounted for nearly two thirds of loans outstanding and deposits (BoyreauDebray and Wei 2005).

3. For example, due to their inability to import machinery and equipment necessary to comply with an export contract. 
This criticism of export-oriented FDI in China motivates this paper. Two research questions are addressed: (i) is there a link between access to finance and firms' exports? and (ii) what is the impact of FDI on the exporting behaviour of indigenous enterprises?

The theoretical trade literature has examined the first question from a different perspective. Within an augmented Heckscher-Ohlin model, Kletzer and Bardhan (1987) offer a theory which predicts that countries with well functioning financial systems tend to export goods produced in industries that are heavily dependent on external finance. More recently, Chaney (2005) shows that in the presence of fixed costs associated with exporting, some firms do not export because of liquidity constraints. The second question was first explored empirically by Aitken, Hanson, and Harrison (1997) and their work has spawned related firm level studies across a variety of countries. This paper contributes to the literature by modelling the interaction between finance, FDI and individual firms' exports in what is arguably the most important emerging economy in the world.

The economic literature abounds with studies that examine the relationship between aggregate growth and finance, but there is little research relating to the specific mechanisms linking finance and growth, especially at a micro level (see Levine 2005 for an extensive review) ${ }^{4}$. By focusing on firm level exports, this paper also contribute to research which sheds empirical light on the various channels through which financial development promotes growth.

Our study draws on a rich panel data set of more than 28,000 domestic private enterprises from the Chinese manufacturing sector, spanning the period 1999-2002. This is an interesting period as it coincides with China's accession to the WTO and the further opening of the economy to foreign investors. Four key results emerge from the analysis: (i) Access to bank loans is associated with greater export market orientation, especially amongst politically unaffiliated firms in labour-intensive industries; (ii) Export-oriented horizontal FDI has a robust export enhancing effect, and this effect is more pronounced amongst firms with more finance; (iii) Domestic market seeking horizontal FDI has a deleterious effect on the export market orientation of indigenous firms; (iv) positive export spillovers through vertical linkages with multinational firms are few and far between.

The remainder of this paper is structured as follows. Section II offers a short overview of the development of FDI in China. Section III discusses the theoretical literature linking FDI, finance and exports. Section IV presents the empirical model, and Section V describes the data and offers some

4. Based on cross country growth regressions, Alfaro et al. (2004) find that financial development speeds up the rate of FDI-induced economic growth rates. 
preliminary analysis. The main findings of the paper are discussed in Section VI. Section VII concludes.

\section{FOREIGN-INVESTED FIRMS IN CHINA}

This section provides a brief overview of the trend of FDI flows into China over the past quarter of a century ${ }^{5}$. When the Chinese government initiated economic reforms in the late 1970s, FDI was allowed only in designated Special Economic Zones (SEZs) ${ }^{6}$, and foreign investors were required to have local partners. At that time, FDI was seen by Chinese policy makers as an important vehicle of its export-led and import substitution development strategy. As a result, SEZs granted foreign investors concessionary tax policies and exemption from export and import duties for equipment and machinery employed in the production of export products.

Following the passage of the Wholly Foreign-Owned Enterprise Law in 1986, firms with $100 \%$ foreign capital were allowed to operate in the country for the first time and by 1988 China's Open Door Policy towards FDI extended to the entire coastal zone. The main purpose of this policy initiative was to develop labour-intensive industries that specialise in export processing of imported raw materials. This export-oriented FDI policy has evidently been spectacularly successful, as China is now described as 'the export processing zone of the world' (Lin 2002). The policy of further liberalisation of the economy initiated in 1992 witnessed a dramatic surge in multinational activity in China (see Figure 1). Foreign investors were offered better opportunities to sell their products in the domestic market. As policy makers started to view FDI as a channel of international knowledge transfer which would minimise the need for technology imports, high-tech investors were particularly encouraged.

FDI in China is characterised by an uneven regional distribution. During the period 1987-2000, about $87 \%$ of cumulative FDI was located in the coastal regions (Wei 2003). This was mainly a reflection of the initial policy that restricted FDI to coastal regions. The proximity of those regions to Hong Kong and Taiwan, the main sources of foreign investment, also contributed to these geographical disparities. Although Western and Central regions are gradually attracting more foreign investors, the skewed distribution of FDI in favour of the coastal regions has raised serious concerns that FDI might exacerbate existing regional inequalities (e.g. Bils 2005).

Investment from the Chinese Diaspora of Hong Kong, Taiwan and Macao accounted for more than $60 \%$ of the total accumulated FDI stock in China

5. Some of the material in this section draws on Chen (1997) and Lemoine (2000).

6. The SEZs consisted of three in Guangdong Province: Shenzhen, Zhuhai, Shantou and Xiamen in Fujian Province. 
Figure 1

FDI flows into China, 1979-2003

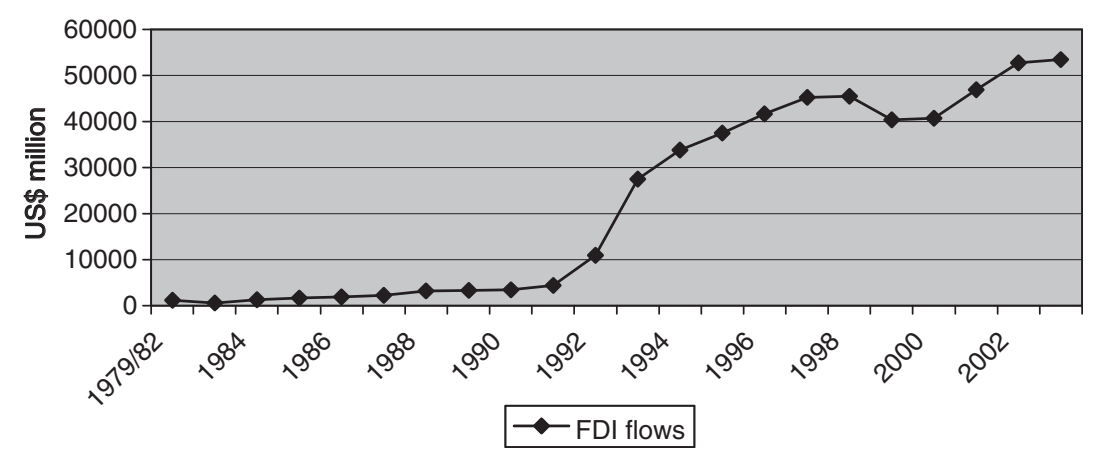

Data Source: China Statistical Yearbook, various issues

between 1983 and 1998 (OECD 2000). This investment is predominantly exportoriented and tends to concentrate in labour-intensive sectors. During this period, multinationals from Japan, USA and Western Europe represented 8.2\%, 8.1\% and $6.7 \%$ of FDI, respectively. Foreign investment from these OECD countries is predominantly in more capital-intensive sectors and is increasingly being motivated by the desire for access to the huge domestic market.

Manufacturing enterprises in China finance their investment from four main sources: (i) state budgets; (ii) domestic bank loans, (iii) self-raised finance, such as that obtained from domestic capital markets and retained earnings, and (iv) foreign financing. A typical foreign-invested enterprise uses a mixture of all sources of finance listed above. Between 1999 and 2002, finance from state budgets, domestic bank loans, self-raised finance and foreign sources accounted for $8 \%, 20 \%, 17 \%$, and $55 \%$ respectively of the total finance of foreign invested firms in Chinese manufacturing ${ }^{7}$. These figures show that multinational firms operating in China make significant use of domestic financial resources.

\section{ACCESS TO FINANCE, EXPORTS AND FDI: THEORETICAL CONSIDERATIONS}

\subsection{Access to Finance and Exports}

International trade theory suggests that financial sector development is a source of comparative advantage and consequently a determinant of international

7. The figures are calculated based on the dataset used in this paper. 
trade flows. Kletzer and Bardhan (1987) extend the Heckscher-Ohlin trade model by introducing a financial sector and predict that a country with a welldeveloped financial sector will have comparative advantage in the export of goods produced in industries that rely more on external financing. Baldwin (1989) develops a model in which finance is an instrument of risk diversification, and shows that firms in financially developed countries enjoy better opportunities for diversification, and therefore specialise in the export of risky goods ${ }^{8}$. Recently Chaney (2005) proposes a theory of international trade which predicts that in the presence of sunk costs associated with exporting, firms with liquidity constraints tend to be non-exporters.

Several channels through which finance generates growth are identified in the theoretical literature. First, financial intermediaries are deemed to be effective at picking entrepreneurs who are more likely to engage in innovative activities. The notion that finance plays a positive role in enhancing the rate of technological innovation dates back to Schumpeter, and recent authors who have explored this idea include De la Fuente and Marin (1996) and Morales (2003). Second, a wellfunctioning financial system has a positive influence on human capital accumulation. For example, Jacoby (1994) shows how access to credit facilitates the process of skill upgrading. Third, financial institutions stimulate economic development by monitoring managers and ensuring that effective corporate governance mechanisms are in place (e.g. Stiglitz and Weiss 1983 and Myers and Majluf 1984). This is expected to induce managers to maximise firm value rather than engage in rent-seeking transactions at the expense of shareholders. Fourth, debts diminish the amount of free cash flow to managers, giving them the incentive to reduce managerial slack and seek innovative ways to boost efficiency (e.g. Aghion et al. 1999). Finally, a well-oiled financial system ameliorates growth prospects by allowing individual agents to diversify and increase their propensity to undertake high return but risky projects. This idea is explored theoretically from different perspectives by Acemoglu and Zilibotti (1997) and King and Levine (1993), amongst others. In light of the well-established proposition that firms which are more efficient, fast growing, invest in technology and skill upgrading have greater likelihood to export (e.g. Bernard et al. 2003, Clerides et al. 1998 and Aw et al. 1999), it can reasonably be hypothesised that access to finance may enhance firms' propensity to export as long as it is growth-enhancing.

\subsection{FDI and Export Spillovers}

The mechanisms through which intra-industry spillovers from FDI occur are well-understood in the literature (see Görg and Greenaway 2004, for a recent

8. Beck (2002) and Svalerdy and Vlachos (2005) offer empirical evidence in support of the hypothesis that finance influences the pattern of international trade. 
review). The entry of multinational firms can impact on domestic firms' output, employment and efficiency through enhanced competition, technology diffusion, export market access and employee training. In particular, FDI may stimulate the exports of domestic enterprises by providing information on international markets and marketing strategies or by enhancing the competitiveness of indigenous firms and by demonstrating new management techniques (Aitken, Hanson, and Harrison 1997).

The early literature has focused on intra-industry FDI spillovers, but Rodríguez-Clare (1996) provides the first theoretical analysis of inter-industry linkage effects generated by multinationals. In a related paper, Markusen and Venables (1999) offer a model in which the entry of multinational firms has two contrasting effects on the domestic economy: FDI crowds out domestic producers of final goods via a competition effect, but at the same time creates favourable conditions to indigenous firms via linkage effects by, for example, increasing the demand of intermediate goods. It is worth noting, however, that neither Rodríguez-Clare (1996) nor Markusen and Venables (1999) have explored explicitly the export-FDI nexus.

\section{EMPIRICAL APPROACH}

This section describes the empirical approach employed to identify the relationship between FDI, access to finance and exporting intensity, defined as the share of exports in total sales. A firm (indexed by $i$ ) either exports at time $t$ with positive exporting intensity or it does not. We formulate a Tobit model of exporting intensity in terms of a latent variable model as:

$$
\begin{aligned}
\text { Export }_{i j t}= & \max \left[0, \gamma_{1} X_{i j t}+\gamma_{2} F D I_{i j t}+\gamma_{3} \text { Bank }_{i j t}+\gamma_{4}\left(F D I_{i j t} * \text { Bank }_{i j t}\right)\right. \\
& \left.+\gamma_{5} D_{i j t}+\varepsilon_{i j t}\right], \varepsilon \sim N\left(0, \sigma^{2}\right)
\end{aligned}
$$

where FDI is a vector of indices of foreign presence ${ }^{9}$ in industry $j$ at time $t$; Bank denotes bank loans normalised by total assets and $\mathrm{X}$ is a vector of firm level characteristics comprising of new product innovation, age, total factor productivity growth ${ }^{10}$, labour training expenditure (normalised by total wage bills), size and self-raised finance normalised by total assets. The choice of these control variables is guided by theoretical considerations and existing empirical evidence (e.g. Bernard and Jensen 2004, Clerides et al. 1998 and Aw et al. 1999).

9. The construction and definition of the variables used the FDI indices will be discussed in more detail in the next section.

10. Total factor productivity (FP) is calculated using the methodology of Levinsohn and Petrin (2003), which accounts for the endogeneity of inputs in the production function estimation. 
Finally $D$ is the full set of industry, time and region dummies and $\varepsilon$ is a random error term.

Arguably a number of regressors in Equation (1) such as horizontal FDI, firm size, productivity growth, labour training expenditure and bank loans are potentially endogenous. Foreign firms are likely to invest in sectors where domestic firms have higher a propensity to export. Also, exporting firms may have some unobserved characteristics which are systematically correlated with their ability to raise finance. These considerations motivate us to use an instrumental variables approach for Tobit models which is due to Smith and Blundell (1986) ${ }^{11}$.

Lagged values of the endogenous regressors are used as instruments, but we also use three additional external instruments. The first is a dummy variable indicating the political/bureaucratic affiliation of the firm. A significant proportion of Chinese privately owned firms is affiliated to some level of government (such as central and local government) for so-called 'supervisory' purposes. This type of bureaucratic affiliation can help firms obtain credit guarantees (Huang 2004). As such this variable is likely to be a relevant instrument for the finance variable ${ }^{12}$. The remaining two additional variables are designed to instrument both FDI and access to finance, and these are the output share of state-owned enterprises (SOEs) and the proportion of loss making SOEs in the firms' sector and region. These variables affect the extent of bank access by private firms, given the lending bias in favour of SOEs, particularly poorly performing ones. Moreover, Huang (2003) argues convincingly that a sizeable proportion of recent FDI (especially joint ventures and acquisitions) in China has resulted from the insolvency problems facing SOEs. Thus it is reasonable to suppose that the output share of SOEs and the proportion of loss making SOEs are also sensible instruments for FDI.

The estimation of Tobit models with endogenous regressors involves two steps: (i) running a linear regression of each endogenous regressor on the instrumental variables and all other exogenous regressors, and (ii) estimating the Tobit model by including the residual terms from step (i) in the list of covariates. The residuals are correction terms for the endogeneity problem, and jointly significant coefficients on these terms can be taken as evidence in favour of the hypothesis that the relevant regressors are indeed endogenous.

11. Also see Wooldridge (2001). Newey (1987) suggests a maximum likelihood estimator for discrete models with endogenous regressors. But his estimator fails to converge within our model - a commonly encountered problem when there is more than one endogenous regressor.

12. An exploratory analysis suggests the importance of political affiliation for access. However, we leave a more systematic examination of the political economy of access to finance in China for future work. 


\section{DATABASE DESCRIPTION AND PRELIMINARY ANALYSIS}

Our empirical analysis draws on the Annual Report of Industrial Enterprise Statistics compiled by the State Statistical Bureau of China ${ }^{13}$, covering all firms with an annual turnover for over five million Renminbi (about \$60000). It is estimated that these firms account for more than $85 \%$ of industrial output in China. The report is a rich source of firm level characteristics such as firm ownership structure, industry affiliation, geographic location, establishment year, employment, gross output, value added, and product innovation, sources of finance, exports, and employee training expenditure ${ }^{14}$. The data available to us cover the period 1999 to 2002.

To capture the extent of foreign presence in each industry-region $j$ at time $t$, we define the degree of horizontal FDI, say $H F D I_{j t}$, as the proportion of industry-region output accounted for by multinational companies (MNEs) ${ }^{15}$. This and all other indices of FDI are constructed for 171 three-digit industries within each of the 31 provinces of China. As a result, the FDI variables used in this study show very good sample variability.

Based on $H F D I_{j t}$ we calculate two indices of foreign presence in backward and forward linked industries in line with existing practice (cf. SmarzynskaJavorcik 2004). Backward linkage with FDI in industry $j$ at time $t$ is a proxy for the foreign presence in the industries supplied by industry $j$ at time $t$, and is computed as:

$$
D F D I_{j t}=\sum_{\forall k \neq j} \alpha_{k j} H F D I_{k t}
$$

where $\alpha_{k j}$ is the proportion of sector $j$ 's output supplied to industry $k^{16}$. It is assumed that the greater the proportion of output supplied to an industry with foreign multinational presence, the greater the degree of linkage between foreign and local firms. We refer to this as downstream FDI.

The index of FDI in upstream sectors is calculated in a similar fashion as:

$$
U F D I_{j t}=\sum_{\forall k \neq j} \beta_{k j} H F D I_{k t}
$$

13. Various sub-samples of this data base are now being used in the economic literature. See, for example, Hu et al. (2005).

14. Nominal values are deflated using industry-specific ex-factory price indices obtained from China Statistical Yearbook.

15. Horizontal FDI can also be defined as foreign equity participation weighted by output share and averaged over all firm in the sector (Smarzynska-Javorcik 2004), or weighted by employment share instead (Aitken and Harrison 1999). The different measures of horizontal FDI are found to be highly correlated, however.

16. This information is obtained from the 1997 input-output table of China. 


\section{Table 1}

Output Share and Export Intensity of PRIVATE and Foreign-Invested Enterprises (FIE) by Industry and Region

\begin{tabular}{|c|c|c|c|c|c|c|c|c|}
\hline & \multicolumn{4}{|c|}{ PRIVATE firms } & \multicolumn{4}{|c|}{ FIE enterprises } \\
\hline & \multicolumn{2}{|c|}{$\begin{array}{l}\text { Output } \\
\text { share }\end{array}$} & \multicolumn{2}{|c|}{$\begin{array}{c}\text { Export } \\
\text { intensity }\end{array}$} & \multicolumn{2}{|c|}{$\begin{array}{l}\text { Output } \\
\text { share }\end{array}$} & \multicolumn{2}{|c|}{$\begin{array}{c}\text { Export } \\
\text { intensity }\end{array}$} \\
\hline & 1999 & 2002 & 1999 & 2002 & 1999 & 2002 & 1999 & 2002 \\
\hline \multicolumn{9}{|l|}{ Industry } \\
\hline Capital intensive & 0.037 & 0.114 & 0.129 & 0.149 & 0.298 & 0.308 & 0.439 & 0.44 \\
\hline Labour intensive & 0.044 & 0.123 & 0.135 & 0.148 & 0.311 & 0.336 & 0.434 & 0.44 \\
\hline \multicolumn{9}{|l|}{ Region } \\
\hline Coastal & 0.042 & 0.123 & 0.184 & 0.185 & 0.397 & 0.407 & 0.472 & 0.472 \\
\hline Central & 0.038 & 0.111 & 0.039 & 0.064 & 0.11 & 0.134 & 0.185 & 0.213 \\
\hline Western & 0.042 & 0.105 & 0.029 & 0.026 & 0.088 & 0.089 & 0.141 & 0.146 \\
\hline
\end{tabular}

Notes:

1. Authors' calculations based on the database used in this paper.

2. The following industry are defined as capital intensive: Chemical, electronics, machinery, instruments, automobile, pharmaceutical, petroleum and fibre. A more detailed description is available from the authors upon request.

where $\beta_{k j}$ represents the proportion of sector $k$ 's output supplied to industry $j$. This measure of FDI, which we label upstream FDI, captures the extent of forward linkages local firms in downstream sectors have with MNEs in supplying sectors.

Each of the three FDI indices (viz. HFDI, DFDI and UFDI) is further distinguished by the market orientation of the foreign investment (domestic market seeking versus export-oriented), based on the domestic market sales and export values reported by multinational enterprises.

Table 1 gives the average output share and exporting intensity of privately owned and foreign-owned firms in the database for 1999 and 2002. It is apparent that foreign-owned firms (defined as those with at least $25 \%$ share of foreign capital) have significant presence in both labour-intensive and capitalintensive industries. But it is also clear from Table 1 that foreign-owned firms have substantial interest in serving domestic markets too. It is worth noting that, while the output share of private firms has more than doubled between 1999 and 2002, their average exporting intensity did not exhibit a significant change. Finally, the figures in Table 1 confirm the well-established proposition that the geographic distribution of international commerce activity in China is highly uneven.

The econometric analysis is based on some 28,400 privately owned enterprises that have not received any funds from either foreign channels or state budgets during the sample period. Thus their main sources of finance are bank 
Table 2

Summary Statistics of Variables used in the Regressions

\begin{tabular}{|c|c|c|c|c|c|c|}
\hline & \multicolumn{2}{|c|}{$\begin{array}{c}\text { All } \\
\text { sectors }\end{array}$} & \multicolumn{2}{|c|}{$\begin{array}{l}\text { Labour-intensive } \\
\text { sectors }\end{array}$} & \multicolumn{2}{|c|}{$\begin{array}{c}\text { Capital-intensive } \\
\text { sectors }\end{array}$} \\
\hline & Mean & Std. dv. & Mean & Std. dv. & Mean & Std. dv. \\
\hline Export dummy & 0.2138 & 0.4100 & 0.2202 & 0.4144 & 0.2042 & 0.4031 \\
\hline Export intensity (exporters) & 0.6574 & 0.3581 & 0.6979 & 0.3436 & 0.5921 & 0.3712 \\
\hline Product innovation / total output & 0.0190 & 0.1138 & 0.0120 & 0.0910 & 0.0294 & 0.1406 \\
\hline Training expenditure/employment & 0.0598 & 0.3189 & 0.0456 & 0.2565 & 0.0810 & 0.3933 \\
\hline Size (log employment) & 4.6273 & 0.9386 & 4.6714 & 0.9497 & 4.5611 & 0.9179 \\
\hline Total factor productivity growth & 0.1038 & 0.7663 & 0.1012 & 0.7649 & 0.1078 & 0.7683 \\
\hline Age & 9.2191 & 7.7256 & 8.9452 & 7.4422 & 9.6290 & 8.1145 \\
\hline Bank loans/total assets & 0.5135 & 0.2898 & 0.5020 & 0.2929 & 0.5308 & 0.2841 \\
\hline Self raised finance/total assets & 0.3017 & 0.3211 & 0.3126 & 0.3538 & 0.2854 & 0.2639 \\
\hline Horizontal export-oriented FDI & 0.1045 & 0.1468 & 0.1181 & 0.1557 & 0.0842 & 0.1297 \\
\hline Horizontal market-seeking FDI & 0.1434 & 0.1336 & 0.1471 & 0.1315 & 0.1379 & 0.1364 \\
\hline Upstream export-oriented FDI & 0.0007 & 0.0086 & 0.0006 & 0.0107 & 0.0007 & 0.0036 \\
\hline Upstream market-seeking FDI & 0.0009 & 0.0097 & 0.0009 & 0.0120 & 0.0009 & 0.0046 \\
\hline Downstream export-oriented FDI & 0.0008 & 0.0047 & 0.0010 & 0.0055 & 0.0003 & 0.0030 \\
\hline Downstream market-seeking FDI & 0.0012 & 0.0094 & 0.0016 & 0.0117 & 0.0004 & 0.0041 \\
\hline Observations & \multicolumn{2}{|c|}{40910} & \multicolumn{2}{|c|}{24526} & \multicolumn{2}{|c|}{16384} \\
\hline
\end{tabular}

loans and self-raised finance. Table 2 provides some summary statistics for the variables used in the analysis. About a fifth of the firms have some exporting experience, and this does not vary much between labour- and capital-intensive sectors. It is also interesting to note that the average exporting intensity amongst exporters is quite high.

As might be expected, firms in capital-intensive sectors devote more resources to the training and skill upgrading of their employees, while firms in labour-intensive sectors employ, on average, $9 \%$ more workers than capitalintensive ones. The firms in our dataset have registered an impressive average TFP growth of more than $10 \%$, consistent with the notion that private enterprises are the main drivers of China's recent economic growth (e.g. Allen et al. 2005). Average bank loan normalised by total assets is more than $50 \%$, indicating the appetite private entrepreneurs in China have for bank credit. The ratio of self-raised finance to total assets is also quite high.

We now turn to a discussion of the main findings of the paper.

\section{MAIN FINDINGS AND DISCUSSION}

The instrumental variables model is estimated for the whole sample and for labour-intensive and capital-intensive sectors separately. We do this for two reasons: (i) much of the initial concern regarding export-oriented FDI related 
to labour-intensive sectors (e.g. Huang 2003), and (ii) the two sectors are likely to face different external financing requirements due to their technological differences (cf. Rajan and Zingales 1998).

The marginal effects from the Tobit models are reported in Table 3. The null hypothesis of exogeneity of regressors is emphatically rejected in all models, vindicating the use of the instrumental variables estimator. In line with existing empirical evidence, firm size and productivity growth are found to exert positive and economically significant impacts on the propensity to export. For example, according to the IV Tobit model, a 10 percentage points increase in firm size is associated with a 3 percentage points increase in exporting intensity for the average firm. Product innovation is also found to have positive effects on exporting. The exporting impact of product innovation is more pronounced in capital-intensive sectors, where the deployment of new product processes is arguably more crucial for competition in international markets. By contrast, the export market effect of employee training is more important in labour-intensive industries, suggesting that skill upgrading is particularly important in traditional industries seeking to engage in international commerce.

\subsection{Access to Finance, FDI and Exports}

The estimates indicate that access to formal financial channels (i.e. bank loans) enhances the exporting intensity of private firms in China. This effect is more pronounced in labour-intensive industries. By contrast, the exporting impact of self-raised finance is insignificant in capital-intensive industries. Thus it seems that exports in capital-intensive are highly dependent on access to external financing and cannot be financed through internal cash flows alone. This is an interesting finding in view of the idea developed by Rajan and Zingales (1998) that a firm's dependence on external finance is a function of its technological characteristics.

We find that export spillovers from FDI in China exhibit substantial heterogeneity. Firstly, export-oriented horizontal FDI has a robust export enhancing effect, consistent with the belief that exporting multinationals transmit information about the international markets to their local counterparts. Secondly, this positive externality from export-oriented FDI is more marked in labour-intensive industries and for firms with more access to bank loans. Thus access to finance not only has an unconditional impact on exporting, but also helps domestic firms take better advantage of the externalities generated by exporting multinationals in their sector. Thirdly, market seeking horizontal FDI has a deleterious effect on the export market orientation of domestic firms. This effect is more pronounced amongst firms in labourintensive industries with access to bank loans. One interpretation of this result 


\section{JUN DU/SOURAFEL GIRMA}

\section{Table 3}

Access to Bank Loans, Exports and FDI Spillovers

Dependent variable:

Exporting intensity

IV TOBIT

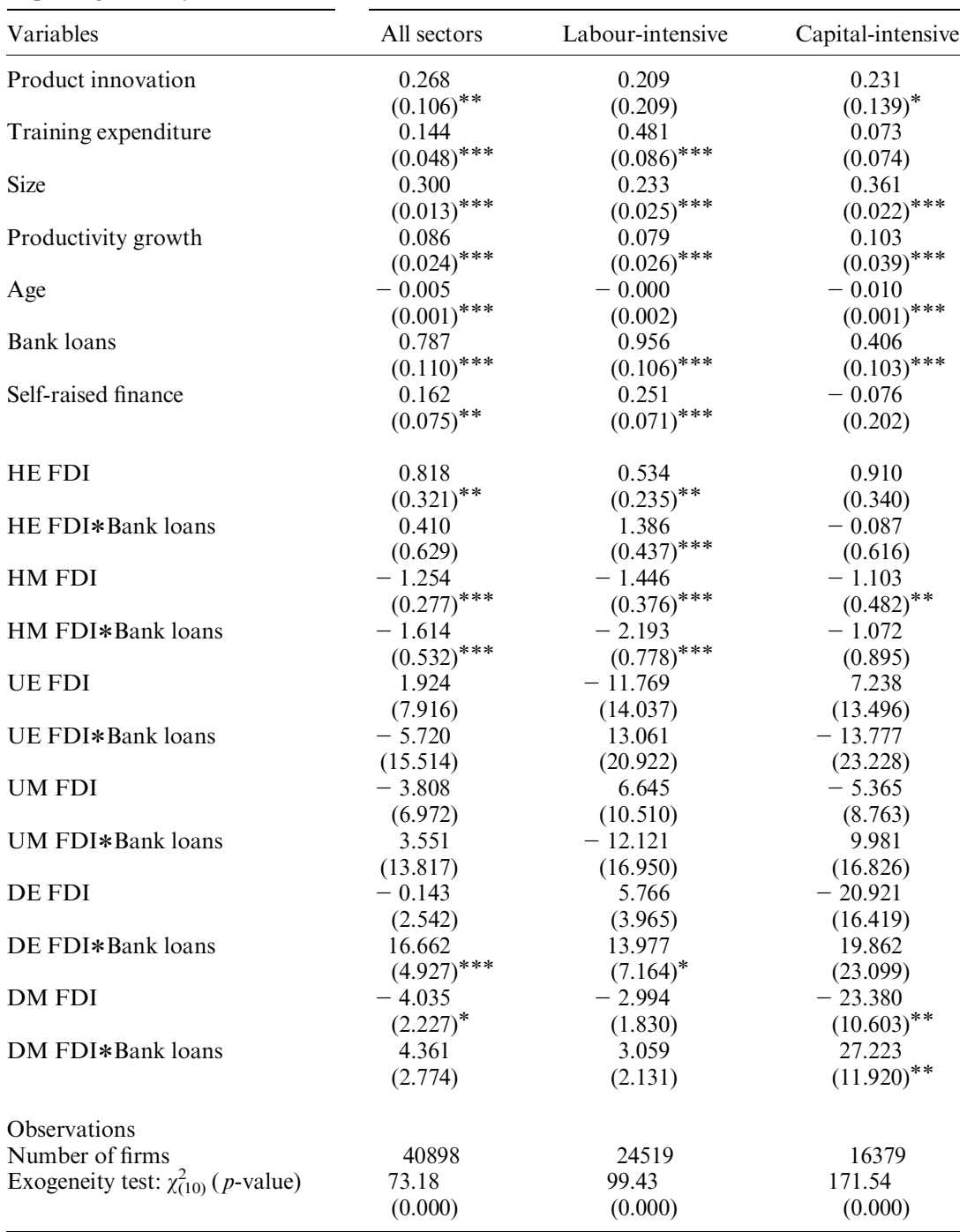

Note 1: Asymptotic standard errors in parentheses.

Note $2:{ }^{*}$ significant at $10 \% ;{ }^{* *}$ significant at $5 \% ;{ }^{* * *}$ significant at $1 \%$.

Note 3: All specifications include time, regional and industry dummies. 
would be that domestic enterprises in labour-intensive industries need to borrow more to invest in protecting their domestic market shares from market seeking multinationals. Fourthly, export-oriented FDI in downstream sectors does not have any sizeable impact on the export of domestic firms. This would appear to suggest that exporting multinationals in China do not substantially source locally - or at least their interaction with their domestic intermediate input suppliers does not generate significant exporting opportunities for the latter. Fifthly, market-seeking FDI in downstream sectors leads to a decrease in domestic firms' exporting intensity. It seems that indigenous enterprises supplying intermediate inputs to domestically-oriented multinationals tend to be more domestically-oriented themselves, other things constant. Finally, we found no significant relationship between domestic exports and FDI in upstream sectors, irrespective of the market orientation of multinationals.

\subsection{Are Private Firms with Political Affiliation Different?}

Many privately owned enterprises in China are affiliated to some level of government administration. Such privately owned firms with political connections are colloquially known as 'red-hat' firms (Huang 2004). The function of the relevant government body is to offer credit guarantees and political protection, in return for some 'management fees ${ }^{17}$.

We conjecture that politically affiliated firms face 'softer' budget constraints since they are likely to be bailed out by the relevant state body should they default on their loans. An interesting question in this respect is whether politically unaffiliated or 'purely' private firms make more efficient use of external finance compared to their 'red-hat' counterparts. To explore this issue, we divide the firms in our sample into 'purely' private and 'red-hat', and estimate the exporting intensity equation on each sub-sample. The results are reported in Table 4 and they indicate that 'purely' private firms utilise bank loans more efficiently, as far as the growth of export is concerned. Interestingly, the export-promoting effect of bank loans is insignificant for 'red-hat' firms in capital-intensive industries. While it is well documented that the Chinese financial system channels substantial resources towards inefficient state-owned enterprises (Allen et al. 2005 and Boyreau-Debray and Wei 2005), our finding provides preliminary evidence that resource misallocation by the banking sector induced by political bias exists even when the analysis is confined to the private sector.

17. Of course bureaucratic/political affiliation may also have its downside, as 'red-hat' firms are likely to encounter some managerial interference from state bureaucrats. 


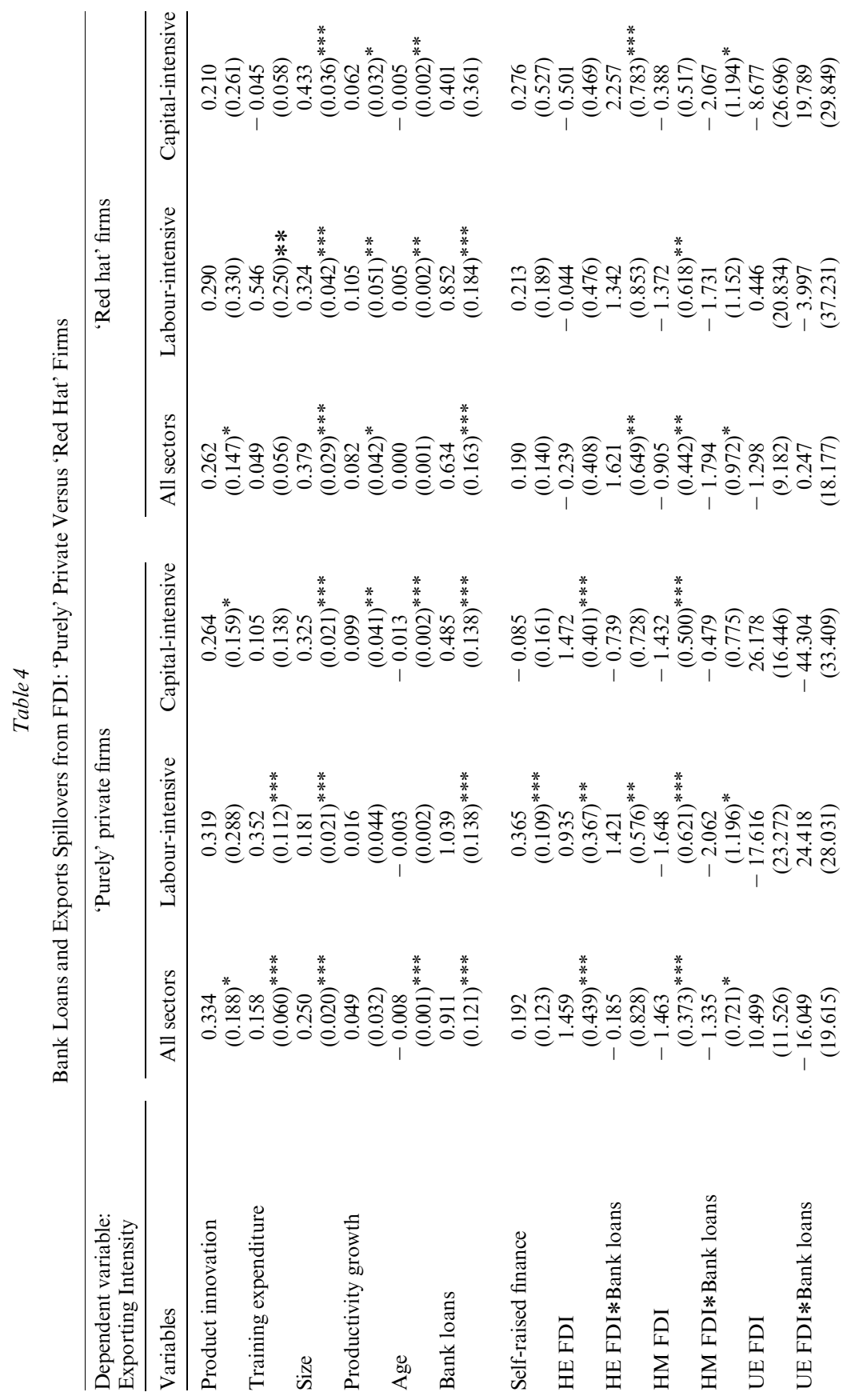


FINANCE AND FIRM EXPORT IN CHINA

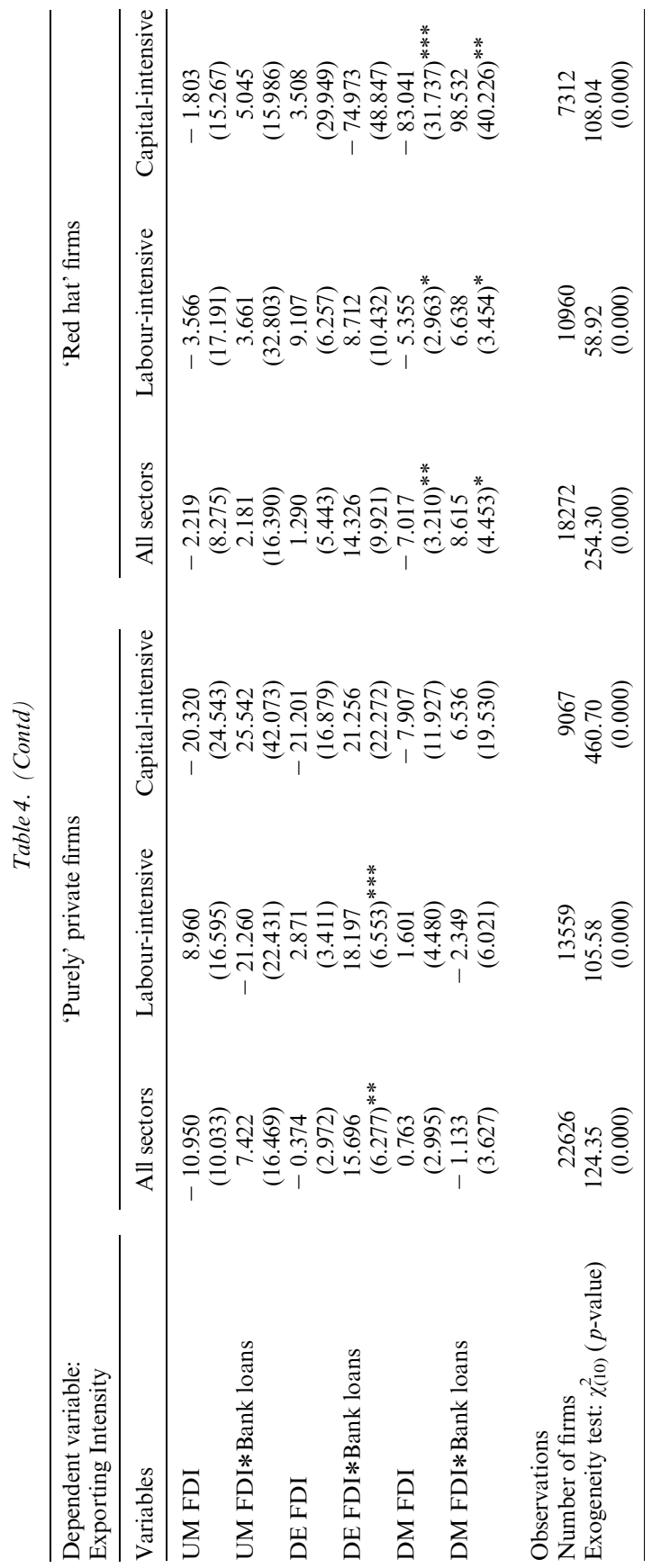




\subsection{Policy Implications}

Until the late 1990s, private enterprises in China were allowed only to export through state-owned trading corporations. Even then, they did not have the right to retain foreign exchange earnings from their exports in a bank account. While this type of blatant discrimination no longer prevails, private firms still suffer from financial repression, especially those without political connections.

In emerging nations like China, exporting benefits firms in many ways. Most notably, it is a channel of international technology transfer (Kraay 1999), creates jobs and generates vital foreign exchange, and hence facilitates the imports of technology. Our finding that more finance generally means more exports, whereas more FDI (especially market-oriented FDI) can mean fewer export, has an important policy implication. To foster the exports of domestic firms, restructuring the financial system is a more potent policy option than relying on FDI spillovers. This is even more relevant as the scope for ensuring the flow of the 'right kind' of FDI which generates export spillovers is now rather limited, since placing performance requirements on foreign investors is against the rules of the WTO, which China joined in 2001.

\section{CONCLUSION}

Using a rich panel data set comprising more than 28,000 privately owned enterprises in China, this paper provides a systematic analysis of the relationship between access to finance, FDI and the export of domestic firms. Controlling for the endogeneity and heterogeneity of finance and FDI, we find that access to bank loans is associated with greater export market orientation, especially amongst politically unaffiliated firms in labour-intensive industries. Export-oriented horizontal FDI is also found to have a robust export enhancing effect, and this positive externality is larger for firms which enjoy better access to finance. By contrast, domestic market seeking horizontal FDI has a deleterious effect on the export orientation of indigenous firms and robust positive export spillovers through vertical linkages with multinationals are rather rare. These findings suggest that rather than rely on FDI to generate export spillovers, the elimination of financial discrimination against private firms is a more effective way of boosting the exports of indigenous enterprises. The present paper has the important broad implication that the expansion of exports is an additional reason why China should undertake the reform of its state-dominated banking system.

\section{REFERENCES}

Aitken, B.J. and A.E. Harrison (1999). Do Domestic Firms Benefit from Direct Foreign Investment? Evidence from Venezuela, American Economic Review. 89: 605-618. 
Acemoglu, D. and F. Zilibotti (1997). Was Prometheus Unbound by Chance? Risk, Diversification, and Growth, Journal of Political Economy. 105: 709-775.

Aghion, P., M. Dewatripont and P. Rey (1999). Competition, Financial Discipline and Growth, Review of Economic Studies. 66: 825-852.

Aitken, Brian, Gordon H. Hanson and Ann E. Harrison (1997). Spillovers, Foreign Investment, and Export Behavior, Journal of International Economics. 43: 103-132.

Alfaro, Laura, Areendam Chanda, Sebnem Kalemli-Ozcan and Selin Sayek (2004). FDI and Economic Growth Rates: The Role of Local Financial Markets, Journal of International Economics. 64: 89-112.

Allen, F., J. Qian and M. Qian (2005). Law, Finance, and Economic Growth in China, Journal of Financial Economics. 77: 57-116.

Aw, B.Y., S. Chung and M.J. Robert (1999). Productivity and Turnover in the Export Market: Micro Evidence from Taiwan and South Korea, The World Bank Economic Review. 14: 65-90.

Baldwin, R.E. (1989). Exporting the Capital Markets: Comparative Advantage and Capital Market Imperfections, in: David B. Audretsch, Leo Sleuwaegen and Hideki Yamawaki (eds.), The Convergence of International and Domestic Markets. North-Holland: Amsterdam: 135-152.

Beck, T. (2002). Financial Development and International Trade: Is There a Link? Journal of International Economics. 57: 107-131.

Bernard, A.B., J. Eaton, B. Jensen and S.S. Kortum (2003). Plants and Productivity in International Trade, American Economic Review. 93: 1268-1290.

Bernard, A.B. and J.B. Jensen (2004). Why Some Firms Export? Review of Economics and Statistics. 86: $561-569$.

Bils, Barbara (2005). What Determines Regional Inequality in China? - A Survey of the Literature and Official Data. Working Paper 2005/04. Bank of Finland http://www.bof.fi/bofit/eng/ 7online/05abs/05pdf/bon0405.pdf.

Boyreau-Debray, Genevieve and Shang-Jin Wei (2005). Pitfalls of a State-Dominated Financial System: The Case of China. NBER Working Paper 11214.

Chaney, Thomas (2005). Liquidity Constrained Exporters. Mimeo: MIT.

Chen, Chunlai (1997). Provincial Characteristics and Foreign Direct Investment Location Decision Within China, Chinese Economy Research Unit Working Paper No. 97/16, University of Adelaide.

Clerides, S., S. Lach and J. Tybout (1998). Is learning by Exporting Important? Micro-Dynamic Evidence from Columbia, Mexico and Morocco, Quarterly Journal of Economics. 113: 903-948.

De la Fuente, A. and J.M. Marin (1996). Innovation, Bank Monitoring, and Endogenous Financial Development, Journal of Monetary Economics. 38: 269-301.

Görg, H. and D. Greenaway (2004). Much Ado About Nothing? Do Domestic Firms Really Benefit from Foreign Direct Investment? World Bank Research Observer. 19: 171-197.

Hu, A.G.Z, G.H. Jefferson and Q. Jinchang (2005). R\&D and Technology Transfer: Firm Level Evidence from Chinese Industry, Review of Economics and Statistics, forthcoming.

Huang, Yasheng (2003). Selling China. Cambridge University Press.

Huang, Yasheng (2004). Why More May be Actually Less? Financing Bias and Labor-Intensive FDI in China, in Financial Sector Reforms in China. Harvard University Press, 2004.

Jacoby, H.G. (1994). Borrowing Constraints and Progress Through School: Evidence from Peru, Review of Economics and Statistics. 76: 151-160.

King, R.G. and R. Levine (1993). Finance, Entrepreneurship, and Growth: Theory and Evidence, Journal of Monetary Economics. 32: 513-542.

Kletzer, K. and P. Bardhan (1987). Credit Markets and Patterns of International Trade, Journal of Development Economics. 27: 57-70.

Kraay, A. (1999). Exports and Economic Performance: Evidence From a Panel of Chinese Enterprises, Revue d'Economie du Développement. 1-2: 183-207. 
Lemoine, F. (2000). FDI and the Opening Up of China's Economy, CEPII Working Paper, No. 00-11.

Levine, Ross (2005). Finance and Growth: Theory and Evidence. Forthcoming in Handbook of Economic Growth.

Levinsohn, J. and A. Petrin (2003). Estimating Production Functions Using Inputs to Control for Unobservables, Review of Economic Studies. 70: 317-342.

Lin, Y. (2002). China's accession to WTO: Exaggerated Fears? UNCTAD Discussion Papers, No. 165.

Markusen, J. and A. Venables (1999). Foreign Direct Investment as a Catalyst for Industrial Development, European Economic Review. 43: 335-356.

Myers, S.C. and N. Majluf(1984). Corporate Financing and Investment Decisions when Firms Have Information that Investors Do Not Have, Journal of Financial Economics. 13: 187-221.

Morales, M.F. (2003). Financial Intermediation in a Model of Growth Through Creative Destruction, Macroeconomic Dynamics. 7: 363-393.

Newey, W.K. (1987). Efficient Estimation of Limited Dependent Variables Models with Endogenous Explanatory Variables, Journal of Econometrics. 36: 231-250.

OECD (2000). Main Determinants and Impacts of Foreign Direct Investment on China's Economy. Working Paper on International Investment No. 2000/4. OECD.

Rajan, R. and L. Zingales (1998). Financial Dependence and Growth, American Economic Review. 88: 559-586.

Rodríguez-Clare, Andres (1996). Multinationals, Linkages, and Economic Development, American Economic Review. 86: 852-873.

Smarzynska-Javorcik, Beata (2004). Does Foreign Direct Investment Increase the Productivity of Domestic Firms? In Search of Spillovers Through Backward Linkages, American Economic Review. 94: 605-627.

Smith, R.J. and R.W. Blundell (1986). An Exogeneity Test for a Simultaneous Equation Tobit Model with an Application to Labor Supply, Econometrica. 54: 679-685.

Stiglitz, J. and A. Weiss (1983). Incentive Effects of Terminations: Applications to Credit and Labor Markets, American Economic Review. 73: 912-927.

Svaleryd, Helena and Vlachos, Jonas (2005). Factor Supplies and the Direction of Technological Change, CEPR Discussion Papers 5086, CEPR Discussion Papers.

Wei, Y. (2003). Foreign Direct Investment in China, Lancaster University Management School Working Paper 2003/002.

Wooldridge, Jeffrey M. (2001). Econometric Analysis of Cross Section and Panel Data. Second Edition, MIT Press.

\section{SUMMARY}

Using a rich panel data set, we provide a rigorous analysis of the relationship between access to external finance, foreign direct investment and the exports of private enterprises in China. We conclude that, in order to foster the exports of indigenous enterprises, the elimination of financial discrimination against private firms is likely to be a more effective policy tool than the reliance on spillovers from multinational firms. 